\title{
DERMOSCOPY OF THE MONTH Nevi with Site-Related Atypia
}

\author{
Tanja TIRNANIĆ 1 , Dimitrije BRAŠANAC ${ }^{2}$, Lidija KANDOLF SEKULOVIĆ³ \\ ${ }^{1}$ City Institute for Skin and Venereal Diseases, Belgrade \\ ${ }^{2}$ Department of Dermatovenereology, Faculty of Medicine, Military Medical Academy, University of Defence, Belgrade \\ ${ }^{3}$ Institute of Pathology, Faculty of Medicine, University of Belgrade \\ *Correspondence: Tanja Tirnanić, City Institute for Skin and Venereal Diseases, Džordža Vašingtona 17, Belgrade 11000, \\ Serbia, E-mail: storebarce@gmail.com \\ UDC 616.5-006-031-07 \\ UDC 616.5-006-031-091.8
}

\begin{abstract}
The term "nevi of special sites" refers to melanocytic nevi of specific anatomic locations including the breast, axillae, umbilicus, genitalia, flexural areas, acral surfaces, ear, scalp and the conjunctiva. Nevi from these anatomic sites display sometimes dermoscopic and histological features of melanoma, resulting in unnecessarily high rates of excisions and re-excisions. Some authors have categorized nevi excised in the axillary, breast, umbilical and perineal areas as the nevi of the milk line. Two patients, a 32-year-old female and 23-year-old male with breast and periumbilical pigmented lesions, presented to our Department during 2017. Dermoscopy revealed features that were highly specific for melanoma. Excisional biopsies were done and histopathology revealed benign nevi with present site-related atypia. Irregular blotches, non-uniform radial streaks, blue-gray veil, and regression are the most specific features of melanoma of the breast and flexural areas. Excision is always recommended in pigmented lesions on the breast and flexural areas, which exhibit these features. However, larger studies are needed to define specific criteria required to distinguish special-site nevi from melanoma.
\end{abstract}

Key words: Nevus, Pigmented; Skin Neoplasms; Breast; Umbilicus; Dermoscopy; Melanoma; Case Reports; Histology

\section{Introduction}

The term "nevi of special sites" refers to melanocytic nevi of specific anatomic locations including the breast, axillae, umbilicus, genitalia, flexural areas, acral surfaces, ear, scalp and the conjunctiva. Nevi from these anatomic sites display sometimes dermoscopic and histological features of melanoma, resulting in unnecessarily high rates of excisions and re-excisions (1). Breast nevi have been reported to have significantly higher levels of histologic atypia than nevi from other sites (2). Excision of such lesions from the breast and chest area in women can lead to poor cosmetic or functional results (3). Umbilical nevi have been described as a form of flexural nevi, which have been reported to have more significant atypia and prominent fibrosis (4). Some authors have categorized nevi excised in the axillary, breast, umbilical and perineal areas as the nevi of the milk line (5). Dermoscopy is the most useful diagnostic

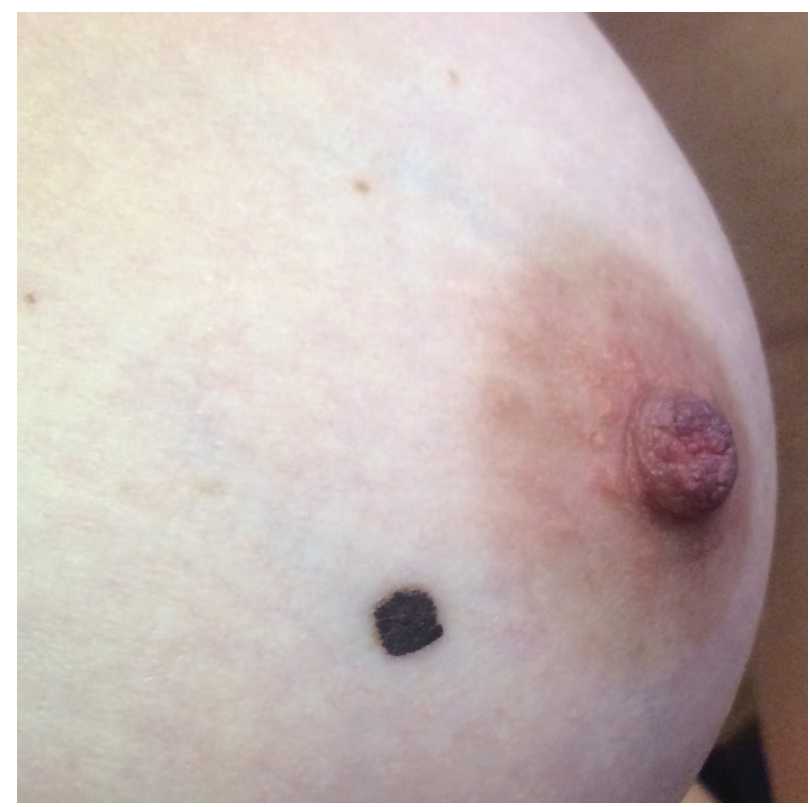

Figure 1. Slightly elevated brownish papule with irregular border on the breast 


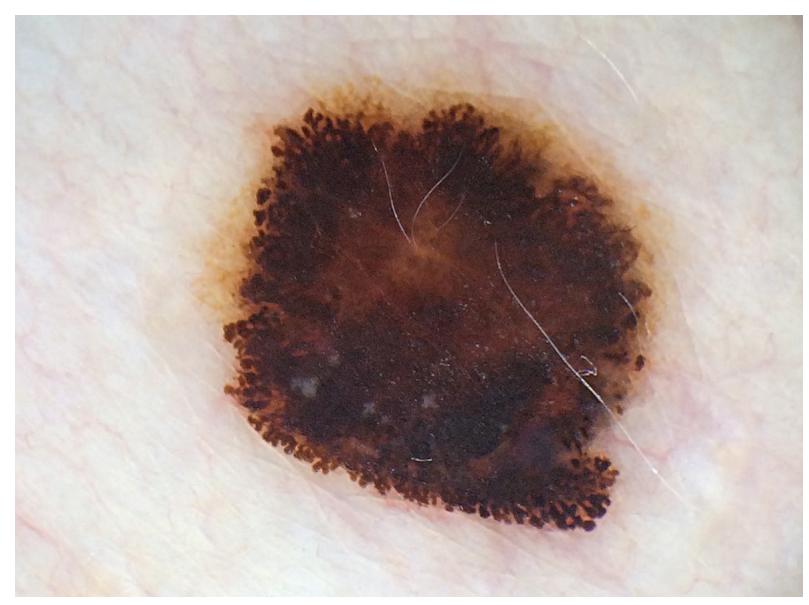

Figure 2. Dermoscopy of the pigmented lesion on the breast: atypical pigment network with irregular globules, pseudopods and radial streaming and multiple blue-gray dots at the periphery of the lesion

method for visualizing morphologic structures beyond the epidermis (3).

\section{Case Reports}

\section{Case 1}

A 32-year-old woman presented to our Department in May 2017 with a pigmented lesion on her left breast. She had noticed an asymptomatic small brownish-black papule $9 \times 4 \mathrm{~mm}$ in diameter that did not change in the size or color over the previous period of more than 5 years. The patient reported negative family history of skin cancer. The physical examination revealed a round, slightly elevated brownish papule with irregular border which was homogenous in color to the naked eye (Figure 1). The regional lymph nodes were not palpable. Dermoscopy revealed atypical pigment network with irregular globules, pseudopods and radial streaming and multiple blue-gray dots at the periphery of the lesion (Figure 2). The excision of the lesion was recommended because of high suspicion for superficial spreading melanoma. The histological examination of the excisional biopsy showed large, rounded, coalescing, pigmented junctional melanocytic nests, melanocytes without nuclear polymorphism and with no mitotic activity (6). The histologic finding was specific for junctional nevus with the present site-related atypia (Figure 3).

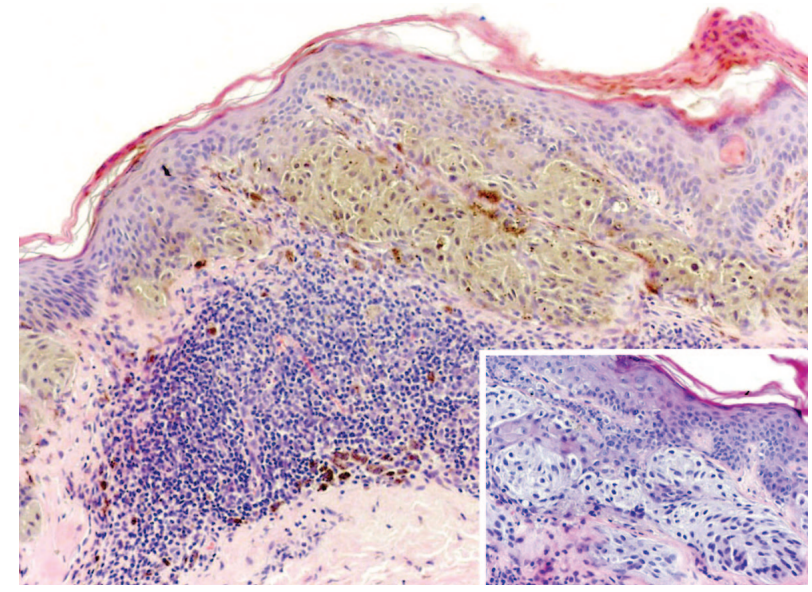

Figure 3. Site-related atypia in junctional nevus with large, confluent pigmented nests and bandlike lymphocytic infiltrate; no increase in nuclear cytoplasmic ratio, no prominent nucleoli and no mitotic figures are evident at higher power magnification (inset) (hematoxylin-eosin, original magnification 100x, hematoxylin-eosin with melanin bleaching, 200x (inset)

\section{Case 2}

A 23 year old man presented to our Department in June 2017 with a periumbilical pigmented lesion. He had noticed an asymptomatic small brown papule about 4 years before. The papule enlarged rapidly during the first year after it had appeared. The patient reported that his father had melanoma. The physical

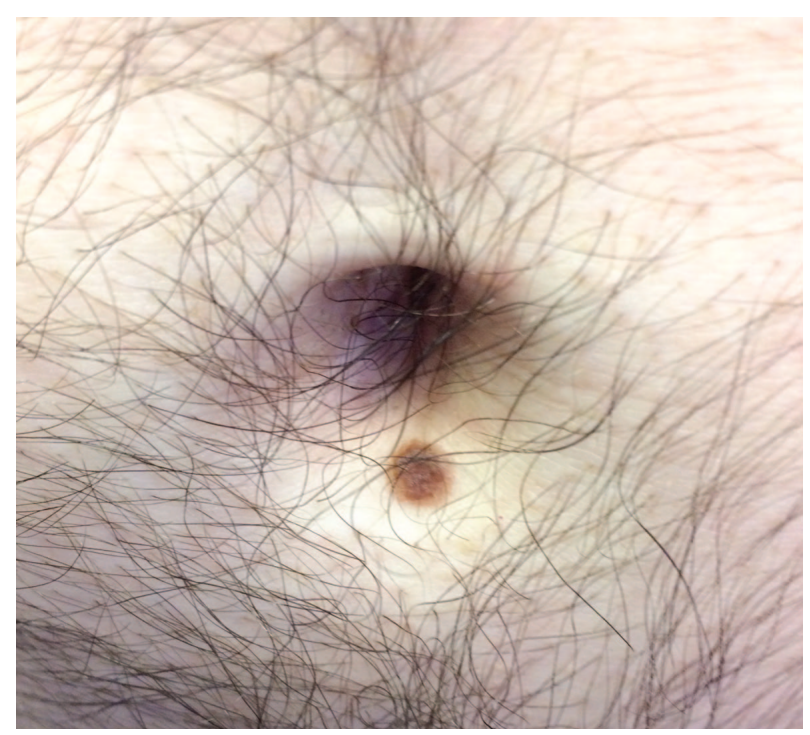

Figure 4. Periumbilical pigmented lesion 
examination revealed round, slightly elevated brown papule, $13 \times 5 \mathrm{~mm}$ in size (Figure 4). Dermoscopy showed an atypical pigment network with irregular globules and pseudopods at the periphery of the lesion (Figure 5). The leading diagnosis was dysplastic nevus, the possibility of melanoma was considered because of the patient's positive family history and the lesion was excised. Histopathology revealed a compound nevus with larger, slightly irregular and focally confluent junctional nests, and lamellar fibrosis extending into dermis, entrapping some small dermal nests (7) (Figure 6).

\section{Discussion}

Nevi of special sites have distinct dermoscopic and histological features that may raise concern for melanoma (8).

The breast nevus in our first case exhibited an atypical pigment network with irregular globules, pseudopods and radial streaming with multiple regression structures (blue-gray dots) at the periphery of the lesion. Dermoscopy of the periumbilical lesion in the second

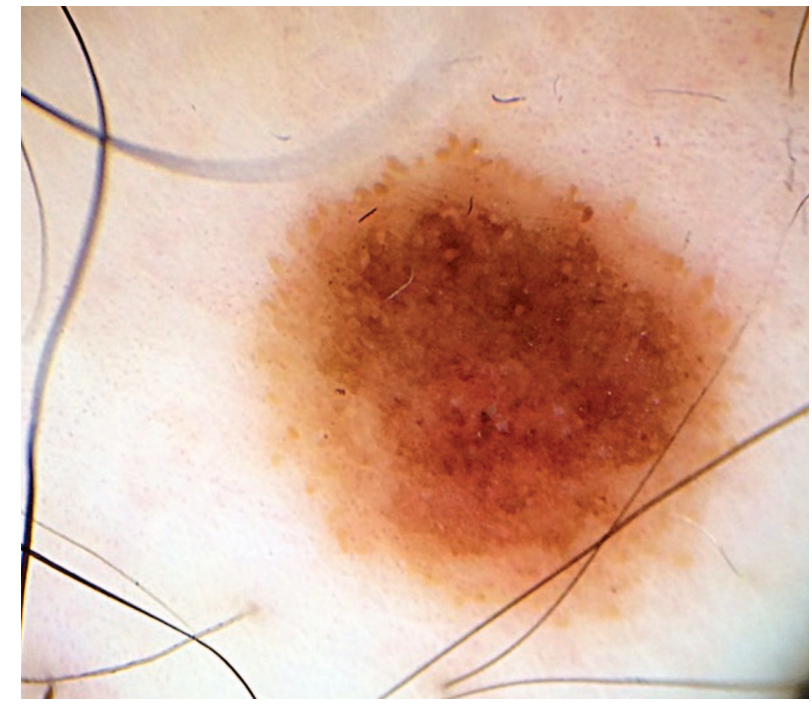

Figure 5. Dermoscopy of the periumbilical pigmented lesion: atypical pigment network with irregular globules and pseudopods at the periphery of the lesion

case showed an atypical pigment network with irregular globules and pseudopods at the periphery of the lesion.

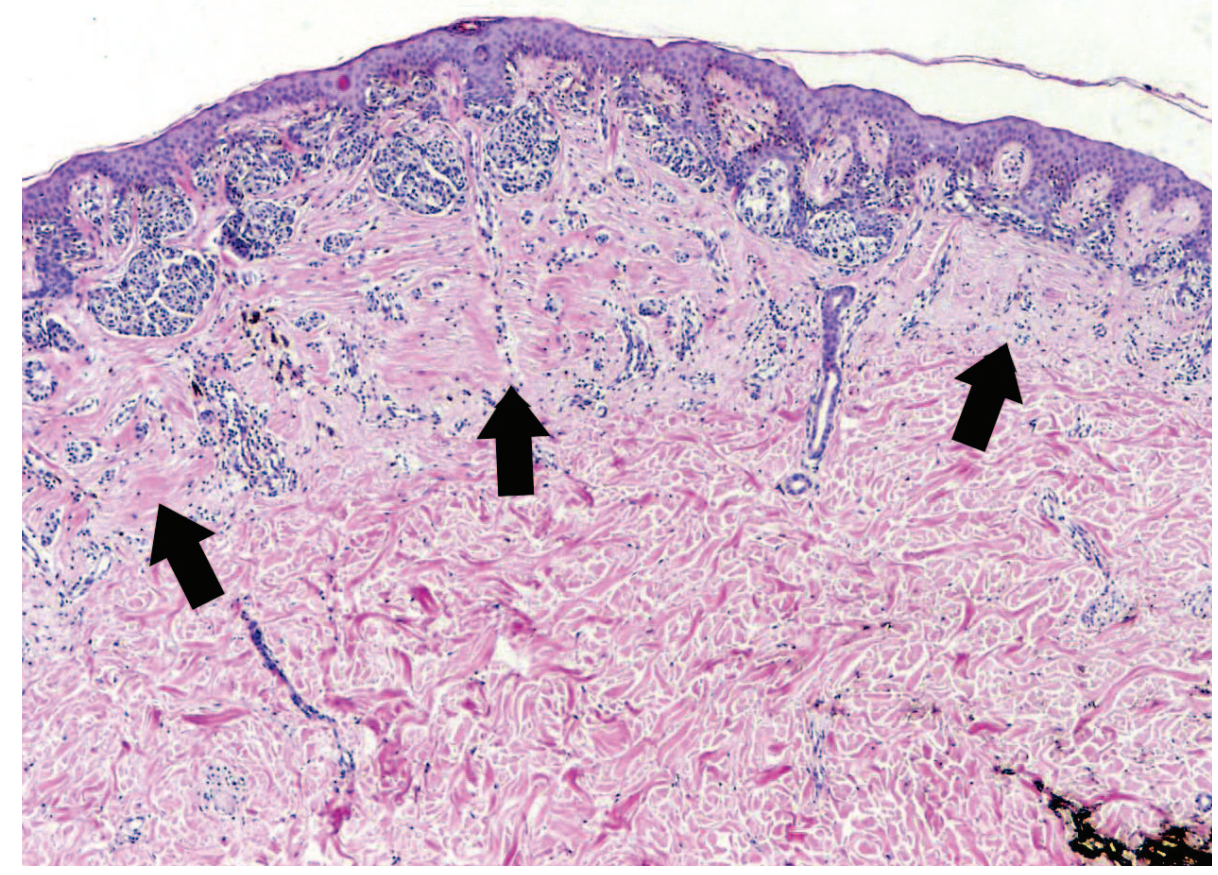

Figure 6. Site-related atypia in umbilical nevus - compound nevus with larger, slightly irregular and focally confluent juntional nests, and lamellar fibrosis extending into dermis (arrows), entrapping some small dermal nests (hematoxylin-eosin, original magnification 40x) 
There are only a few case reports describing dermoscopic features of flexural nevi, including the nevi form the umbilical area. Some authors have categorized nevi in the axillary, breast, umbilical and perineal areas as the nevi of the milk line. The only published retrospective study of the dermoscopic features of 104 nevi and 13 melanomas from the breast and chest, reported by Merkel et al., found that the atypical pigment network and irregular dots and globules were more common than regular distributions of these features, although there was no statistically significant association between these patterns and diagnosis (3). This is in contrast to studies that did not take into consideration specific anatomic locations, in which atypical pigment network and irregular dots and globules were highly specific for melanoma $(9,10)$. Dermoscopic criteria that were highly specific for melanoma of the breast included asymmetric blotches, non-uniform radial streaks, blue-white veil, and regressionlike structures, which was not the case in our patient with the breast nevus. Melanomas were significantly larger (median $7 \mathrm{~mm}$,) than nevi (median $5 \mathrm{~mm}$ ). The majority of women have not reported any evolution in the lesion which is in accordance with our first case (3).

Histologically, breast nevi often have large coalescing junctional melanocytic nests, scattered, irregular intra-epidermal melanocytes above the basal layer, larger melanocytes with some atypia and dermal fibroplasia $(1,2)$. Rongioletti et al. have reported that breast nevi exhibit more atypical features than nevi from other sites. In particular, breast nevi showed higher tendency to have intra-epidermal melanocytes above the basal layer, atypical cytologic features, and papillary fibroplasia (2).

Rongioletti et al. who had examined 40 flexural nevi including 13 cases taken from the umbilicus, found that more than a half of these flexural nevi displayed a nested and dyshesive pattern, which was also the case with our patient (4).

\section{Conclusion}

Irregular blotches, non-uniform radial streaks, blue-gray veil, and regression are the most specific features of melanoma of the breast and flexural areas. Excision is always recommended in pigmented lesions on the breast and flexural areas, which exhibit these features. However, larger studies are needed to define specific criteria required to distinguish special-site nevi from melanoma. It is important to achieve the balance between the careful surveillance of lesions for any clinical or dermoscopic atypia and the prevention of unnecessary excisions.

\section{References}

1. Mason AR, Mohr MR, Koch LH, Hood AF. Nevi of special sites. Clin Lab Med. 2011;31(2):229-42.

2. Rongioletti F, Urso C, Batolo D, Chimenti S, Fanti PA, Filotico R, et al. Melanocytic nevi of the breast: a histologic case-control study. J Cutan Pathol. 2004;31(2):137-40.

3. Merkel EA, Martini MC, Amin SM, Lee CY, Gerami P. Evaluation of dermoscopic features for distinguishing melanoma from special site nevi of the breast. J Am Acad Dermatol. 2016;75(2):364-70.

4. Rongioletti F, Ball RA, Marcus R, Barnhill RL. Histopathological features of flexural melanocytic nevi: a study of 40 cases. J Cutan Pathol. 2000;27(5):215-7.

5. Nicolau AA, Aschie M. Morphologic and immunohistochemical features of breast nevi. Rom $\mathrm{J}$ Morphol Embryol. 2013;54(2);371-5.

6. Dutt R, Rabinovitz, Singh R, Scope A. Dermoscopic and confocal features of an axillary "special site" nevus. Dermatol Pract Concept. 2017;7(1):55-8.

7. Massi G, LeBoitt PE. Nevi on special sites and nevi in pregnancy. In: Massi G, LeBoitt PE, editors. Histological diagnosis of nevi and melanoma. 2nd ed. Berlin, Heidelberg: Springer-Verlag; 2014. p. 339-54.

8. Arps DP, Fullen DR, Chan MP. Atypical umbilical naevi: histopathological analysis of 20 cases. Histopathology. 2015;66(3):363-9.

9. Argenziano G, Soyer HP, Chimenti S, Talamini R, Corona R, Sera F, et al. Dermoscopy of pigmented skin lesions: results of a consensus meeting via the internet. J Am Acad Dermatol. 2003;48(5):679-93.

10. Annessi G, Bono R, Sampogna F, Faraggiana T, Abeni D. Sensitivity, specificity, and diagnostic accuracy of three dermoscopic algorithmic methods in the diagnosis of doubtful melanocytic lesions. The importance of light brown structureless areas in differentiating atypical melanocytic nevi from thin melanomas. J Am Acad Dermatol. 2007;56(5):759-67. 


\section{Dermoskopske i histološke karakteristike nevusa sa „site related atypia”}

\section{Sažetak}

Uvod. Nevusi posebnih anatomskih lokalizacija predstavljaju melanocitne nevuse koji se nalaze na grudima, aksilama, pregibima, genitalijama, umbilikusu, ušima, poglavini i konjuktivi. U određenim slučajevima, ovakvi nevusi pokazuju dermoskopske i histološke karakteristike melanoma, što rezultuje nepotrebnim ekscizijama i reekscizijama. Prikazi slučaja. Prikazujemo dva slučaja: žena od 32 godine sa pigmentnom lezijom na levoj dojci i muškarac od 23 godine, sa pigmentnom lezijom priumbilikalne regije koji su ambulantno pregledani u Klinici za dermatovenerologiju VMA tokom 2017. godine. Učinjena je dermoskopija obe pigmentne promene koja je pokazala karakteristike visokospecifične za melanom. Učinjena je ekscizija ovih promena i uzorci su poslati na patohistološku analizu. Patohistološki nalaz ovih pigmentnih promena je odgovarao benignim melanocitnim nevusima sa site related atypia-om. Diskusija. Nevusi posebnih anatomskih lokalizacija poka- zuju dermoskopske i histopatološke karakteristike koje mogu biti visokospecifične za melanom. U jedinoj do sada objavljenoj retrospektivnoj studiji (Merkel et al.) koja se bavila dermoskopskim karakteristikama melanocitnih nevusa i melanoma mamarne regije, utvrđeno je mnogo češće prisustvo dermoskopskih karakteristika specifičnih za melanom kod benignih melanocitnih nevusa ove regije. Takođe, nevusi posebnih anatomskih lokalizacija mnogo češće imaju atipične patohistološke odlike u odnosu na nevuse drugih lokalizacija. Zaključak. U slučaju pigmentnih promena sa posebnom anatomskom lokalizacijom (dojke, pregibi), koje pokazuju dermoskopske karakteristike visokospecifične za melanom, uvek je indikovana ekscizija. Neophodne su veće studije koje bi utvrdile jasne dermoskopske kriterijume za razlikovanje melanocitnih nevusa posebnih lokalizacija od melanoma, kako bi se sprečile nepotrebne ekscizije.

Ključne reči: Pigmentni nevus; Kožne neoplazme; Dojka; Umbilikus; Dermoskopija; Melanom; Prikazi slučajeva; Histologija 